\title{
PENGARUH VARIASI GRADASI PADA AGREGAT TERHADAP NILAI KUAT TEKAN CEMENT TREATED BASE (CTB)
}

\author{
${ }^{1}$ Rio Lukman KS, ${ }^{2}$ Suhendra \\ ${ }^{1}$ Mahasiswa Teknik Sipil Universitas Batanghari Jambi \\ ${ }^{2}$ Dosen Fakultas Teknik Univesitas Batanghari Jambi \\ suhendra_domas@yahoo.com
}

\begin{abstract}
ABSTRAK
Cement Treated Base (CTB) adalah lapis pondasi agregat yang distabilisasi dengan semen. Pada dasarnya merupakan pengembangan dari konstruksi Soil-Cement, dengan gradasi dan mutu yang lebih terkendali dan metode pelaksanaan (pencampuran dan penghamparan) yang menyerupai pekerjaan pengaspalan. Gradasi agregat pada dasarnya sangat mempengaruhi besarnya rongga antar butir yang akan menentukan stabilitas dan memberikan kemudahan selama proses pelaksanaan. Tujuan penelitian ini adalah: 1. untuk mendapatkan nilai kuat tekan CTB untuk masing-masing variasi gradasi agregat yang digunakan. 2. untuk mengetahui perbedaan nilai kuat tekan CTB yang yang berada pada kondisi gradasi atas, gradasi tengah dan gradasi bawah dari spesifikasi gradasi lapis pondasi agregat. Data pada penelitian ini yaitu data primer dan sekunder. Hasil penelitian mnunjukan: 1. nilai kuat tekan umur 7 hari untuk gradasi bawah adalah 103,57 kg/cm2, nilai kuat tekan gradasi tengah pada umur 7 hari adalah $111,62 \mathrm{~kg} / \mathrm{cm} 2$, dan nilai kuat tekan gradasi atas pada umur 7 hari adalah $106,20 \mathrm{~kg} / \mathrm{cm} 2$.Nilai kuat tekan umur 28 hari untuk gradasi bawah adalah $142,76 \mathrm{~kg} / \mathrm{cm} 2$, nilai kuat tekan umur 28 hari untuk gradasi tengah adalah $159,63 \mathrm{~kg} / \mathrm{cm} 2$, dan nilai kuat tekan umur 28 hari untuk gradasi atas adalah $153,42 \mathrm{~kg} / \mathrm{cm} 2$. 2. nilai kuat tekan gradasi tengah memiliki nilai kuat tekan lebih tinggi dibandingkan dengan gradasi atas dan gradasi bawah.
\end{abstract}

Kata Kunci : Cement Treated Base, Gradasi, Kuat Tekan

\section{PENDAHULUAN}

Di Indonesia pengembangan Cement Treated Base (CTB ) dimulai pada tahun 1987 di PT. Semen Padang, karena terjadinya over produksi semen di Indonesia. Hal ini mendorong Bina Marga untuk mempelopori penggunaan konstruksi jalan yang menggunakan semen sebagai salah satu komponennya untuk dapat memanfaatkan over produksi semen tersebut dan mengurangi ketergantungan terhadap impor aspal. Penggunaan CTB biasanya pada kontstruksi perkerasan jalan sebagai lapis konstruksi pondasi bawah (Sub Base) atau pondasi atas (Base Course). Pada umumnya CTB banyak digunakan untuk ruas-ruas jalan yang melayani lalu lintas cukup padat dan berat. Pada dasarnya merupakan pengembangan dari konstruksi Soil-Cement, dengan gradasi dan mutu yang lebih terkendali dan metode pelaksanaan (pencampuran dan penghamparan) yang menyerupai pekerjaan pengaspalan.

Agregat merupakan komponen utama dari lapisan perkerasan jalan yaitu mengandung 90\% - 95\% agregat berdasarkan persentase berat atau 75\% - 85\% agregat berdasarkan persentase volume. Gradasi agregat pada dasarnya sangat mempengaruhi besarnya rongga antar butir yang akan menentukan stabilitas dan memberikan kemudahan selama proses pelaksanaan. Gradasi agregat merupakan kondisi agregat yang dapat dibentuk untuk mencapai persyaratan yang di inginkan, tetapi hasil dari campuran agregat tersebut tidak berada pada kondisi yang ideal. Penelitian ini melakukan variasi gradasi yang berbeda yakni gradasi yang berada pada batas atas, tengah dan yang berada pada batas bawah, untuk mengetahui pengaruh variasi gradasi pada agregat terhadap nilai kuat tekan Cement Treated Base (CTB).

\section{Cement Treated Base (CTB)}

Cement Treated Base (CTB) adalah bahan untuk lapis pondasi (Base Course) pada perkerasan lentur (Flexible pavement) dan merupakan pengembangan dari struktur soil cement atau agregat semen (Harry Pamadjaja, Dkk, 2001). Cement Treated Base (CTB) adalah campuran dari agregat halus dan agregat kasar, semen dan air, bahan-bahan tersebut dicampur dalam alat khusus yang dapat menghasilkan campuran beton secara menerus (continous batching) dengan kadar air minimum sehingga dapat dihasilkan campuran dengan slump nol.

CTB sebagai lapisan Base Course atau sub-Base Course mempunyai kelebihan kelebihan dibandingkan dengan agregat biasa maupun konstruksi beton biasa, diantaranya adalah : 
- Lapisan konstruksi CTB tidak peka terhadap air dibandingkan bahan Base Course yang tidak diberi campuran semen. Sifat ini sangat membantu untuk konstruksi dimana muka air tanah tinggi.

- CTB tidak membutuhkan alat transport khusus ( truck mixer ), cukup dengan dump truck biasa.

- CTB tidak membutuhkan curing time seperti beton, dalam waktu tiga hari setelah pemadatan, lapisan CTB sudah dapat dilewati kendaraan, sehingga dapat mengurangi jangka waktu pelaksanaan pekerjaan.

- CTB tidak membutuhkan cetakan dan tulangan.

- CTB tidak membutuhkan siar dIlatasi maupun construction joint.

- CTB tidak terlalu peka terhadap temperatur.

- Proses curing CTB lebih mudah dibandingkan beton dan lebih ekonomis.

Sedangkan untuk kekurangan dari penggunaan CTB adalah :

- Dibandingkan dengan Base Course konvensional, CTB memerlukan alat khusus untuk proses pencampurannya.

- Untuk mendapatkan hasil yang optimal, pelaksanaan CTB membutuhkan pengawasan yang lebih ketat dibandingkan dengan Base Course konvensional walaupun lebih mudah dibandingkan beton biasa (Hananto BS, 1993).

\section{Agregat}

Agregat adalah sekumpulan butir-butir batu pecah, kerikil, pasir atau mineral lainnya, baik berupa hasil alam maupun buatan (SNI 03-1737-1989).

Berdasarkan ukuran butirnya, agregat dapat dibedakan menjadi 2 golongan yaitu: a. agregat kasar ialah agregat yang semua butirnya tertahan di atas saringan 4,75 mm (ASTM C33) atau 5,00 mm (BS 812), b. agregat halus ialah agregat yang semua butirnya lolos saringan 4,75 mm (ASTM C33) atau 5,00 mm (BS 812).

Gradasi agregat adalah distribusi ukuran agregat. Berdasarkan gradasinya, agregat dapat dibedakan menjadi jenis gradasi menerus (continuous grade), gradasi sela/jenjang (gap grade), dan gradasi seragam (uniform grade). Jenis gradasi agregat dapat diketahui melalui pengujian analisa saringan sesuai dengan standar yang berlaku (Pengendalian Mutu Pekerjaan Beton, 2010).

a. Gradasi menerus

Jika agregat terdapat pada semua ukuran butirnya dan terdistribusi dengan baik, maka gradasi demikian disebut gradasi menerus.

b. Gradasi Senjang/bercelah

Agregat dikatakan bergradasi sela jika salah satu atau lebih dari ukuran butir atau fraksi pada satu set saringan tidak ada. Pada nilai faktor air-semen tertentu bila kandungan agregat halus lebih sedikit akan diperoleh kemudahan pengerjaan yang lebih tinggi.

c. Gradasi seragam

Agregat ini mempunyai ukuran yang sama, terdiri dari batas yang sempit dari ukuran fraksi. Agregat seragam biasanya dipakai umyuk agregat bergradasi sela atau untuk memperbaiki agregat yang tidak memenuhi syarat.

Agregat untuk lapis pondasi harus bebas dari bahan organik dan gumpalan lempung atau bahan-bahan lain yang tidak dikehendaki, harus memenuhi ketentuan gradasi dan memenuhi persyaratan yang diberikan dalam tabel 1 dan tabel 2

Tabel 1. Gradasi Agregat CTB

\begin{tabular}{|c|c|c|}
\hline \multicolumn{2}{|c|}{ Ukuran Ayakan } & \multirow{2}{*}{$\%$ Lolos } \\
\hline ASTM & $(\mathrm{mm})$ & \\
\hline $2 "$ & 50 & \\
\hline $1^{1 / 2}$ & 37,5 & 100 \\
\hline $1 "$ & 25,0 & $79-85$ \\
\hline $3 / 8 "$ & 9,5 & $44-58$ \\
\hline No. 4 & 4,75 & $29-44$ \\
\hline No. 10 & 2,0 & $17-30$ \\
\hline No. 40 & 0,425 & $7-17$ \\
\hline No. 200 & 0,075 & $2-8$ \\
\hline
\end{tabular}


Tabel 2. Persyaratan Agregat

\begin{tabular}{lcc}
\hline \multicolumn{1}{c}{ Sifat } & Metode Pengujian & Persyaratan \\
\hline Keausan agregat dengan mesin Abrasi Los Angeles & SNI 2417 : 2008 & Maks. 40\% \\
Butiran pecah, tertahan ayakan 3/8” & SNI 7619:2012 & $95 / 90^{1)}$ \\
Batas Cair & SNI 1967:2008 & $0-25$ \\
Indeks Plasitisitas & SNI 1996:2008 & $0-6$ \\
Hasil kali indeks plastisitas dengan \% lolos ayakan no. 200 & - & Maks. 25 \\
Gumpalan lempung dan butiran-butiran mudah pecah & SNI 03-4141-1996 & Maks. 5\% \\
CBR rendaman & SNI 1744 : 2012 & Min. 90\% \\
Perbandingan persen lolos ayakan no. 200 dan no. 40 & - & Maks. 2/3\% \\
\hline
\end{tabular}

\section{Catatan:}

1) 95/90 menunjukan bahwa 95\% agregat kasar mempunyai muka bidang pecah atau lebih dan 90\% gregat kasar mempunyai muka bidang pecah dua atau lebih.

Sumber : Spesifikasi Umum 2010 (Revisi 3)

Sifat-sifat mekanik agregat

a. Daya lekat

Tekstur yang lebih kasar akan menyebabkan daya lekat lebih besar daya lekat baik ditandai dengan banyaknya partikel agregat yang pecah pada beton.

b. Kekuatan

Kekuatan yang dibutuhkan pada agregat lebih tinggi daripada kekuatan beton karena tegangan sebenarnya yang terjadi pada masing- masing partikel lebih tinggi daripada tegangan nominal yang diberikan.

c. Kekerasan

Kekerasan agregat dapat diukur dengan Los Angeles Test.

Sifat-sifat fisik agregat

a. Specific Gravity (Berat Jenis)

Pengukuran berat jenis dapat dilakukan pada 3 kondisi :

- Apparent Specific Gravity (berat jenis absolut) yaitu perbandingan berat agregat tanpa pori di udara dengan volumenya

- Bulk Specific Gravity (Saturated Surface Dry) yaitu perbandingan berat agregat, termasuk berat air dalam pori dengan volumenya

- Bulk Specific Gravity (Dry) yaitu perbandingan berat agregat, termasuk pori di udara dengan volumenya. Apparent specific gravity berkisar antara 2,5-2,7.

b. Bulk Density ( Berat Volume )

Berat volume adalah berat aktual yang akan mengisi suatu penampung/wadah dengan volume satuan.

c. Porositas dan Absorpsi

Porositas dan absorpsi mempengaruhi daya lekat antara agregat dengan pasta, daya tahan terhadap abrasi, dan mempengaruhi nilai specific gravity.

d. Kadar Air

Berbeda dengan absorpsi yang nilainya tetap sedangkan kadar air nilainya berubah ubah sesuai dengan kondisi cuaca.

\section{Semen}

Semen adalah semen hidrolis yang dihasilkan dengan cara menggiling terak semen portland terutama yang terdiri atas kalsium silikat yang bersifat hidrolis dan digiling bersama-sama dengan bahan tambahan berupa satu atau lebih bentuk kristal senyawa kalsium sulfat dan boleh ditambah dengan bahan tambahan lain. (SNI 15-2049-2004). Semen adalah hasil industri dari paduan bahan baku: batu kapur/gamping sebagai bahan utama dan lempung/tanah liat atau bahan pengganti lainnya dengan hasil akhir berupa padatan berbentuk bubuk/bulk, tanpa memandang proses pembuatannya, yang mengeras atau membantu pada pencampuran dengan air. (Soja Siti Fatimah, 2008)

Semen portland adalah material halus yang terdiri dari bahan-bahan campuran utama seperti kapur, silica alumina, besi dan gypsum. Semen disebut juga bahan pengikat hidrolis karena jika semen 
berhubungan dengan air akan menjadi bahan campuran yang aktif secara kimiawi. Dikutip dari (Ni Made Dwi Desmawaty, 2014), Semen adalah suatu jenis bahan yang memiliki sifat adhesive dan kohesif yang memungkinkan melekatnya fragmen-fagmen mineral lain menjadi suatu massa yang padat.

\section{METODE PENELITIAN}

Penelitian ini merupakan penelitian eksperimen yang dilakukan sesuai dengan prosedur untuk pengerjaan pembuatan CTB. Pembuatan benda uji dilakukan di Laboratorium UPTD Balai Pengujian Dinas PU Provinsi Jambi.

Pengujian kuat tekan dilakukan dengan menggunakan mesin kuat tekan unit test scientific. Kuat tekan silinder diketahui dengan cara memberikan beban secara terus-menerus pada benda uji sampai benda uji tersebut mengalami retakan/kehancuran dan beban yang diperoleh merupakan beban maksimum yang mampu dipikul benda uji.

Pengujian kuat tekan benda uji adalah dilaksanakan pada saat benda uji berumur 7 dan 28 hari dengan jumlah masing-masing benda uji 3 (tiga) buah berbentuk silinder untuk setiap variasi gradasi dengan kadar semen dan kadar air yang telah ditentukan. Untuk menghitung kuat tekan, beban yang digunakan adalah beban maksimum yang diberikan mesin test pada saat benda uji mengalami keretakan/kehancuran.

\section{HASIL DAN PEMBAHASAN}

Kuat tekan pada benda uji dihitung dengan rumus :

$\left(\mathrm{f}^{\prime} \mathrm{c}\right)=\mathrm{P} / \mathrm{A}$

Dimana :

$\mathrm{f}^{\prime} \mathrm{c}=$ Kuat tekan $\left(\mathrm{kg} / \mathrm{cm}^{2}\right)$

$\mathrm{P} \quad=$ Beban maksimum $(\mathrm{kg})$

A = Luas Permukaan benda uji yang mengalami tekan $\left(\mathrm{cm}^{2}\right)$

Hasil perhitungan hasil uji ditabelkan sebagai berikut.

Tabel 3 Kuat Tekan Rata-rata Benda Uji

\begin{tabular}{lcc}
\hline \multicolumn{1}{c}{ Tipe Gradasi } & \multicolumn{2}{c}{ Kuat Tekan rata-rata (kg/cm2 } \\
\hline GB (Gradasi batas Bawah) & Umur 7 hari & Umur 28 hari \\
GT (Gradasi Tengah) & 103,57 & 142,76 \\
GA (Gradasi batas Atas) & 111,62 & 159,63 \\
\hline
\end{tabular}
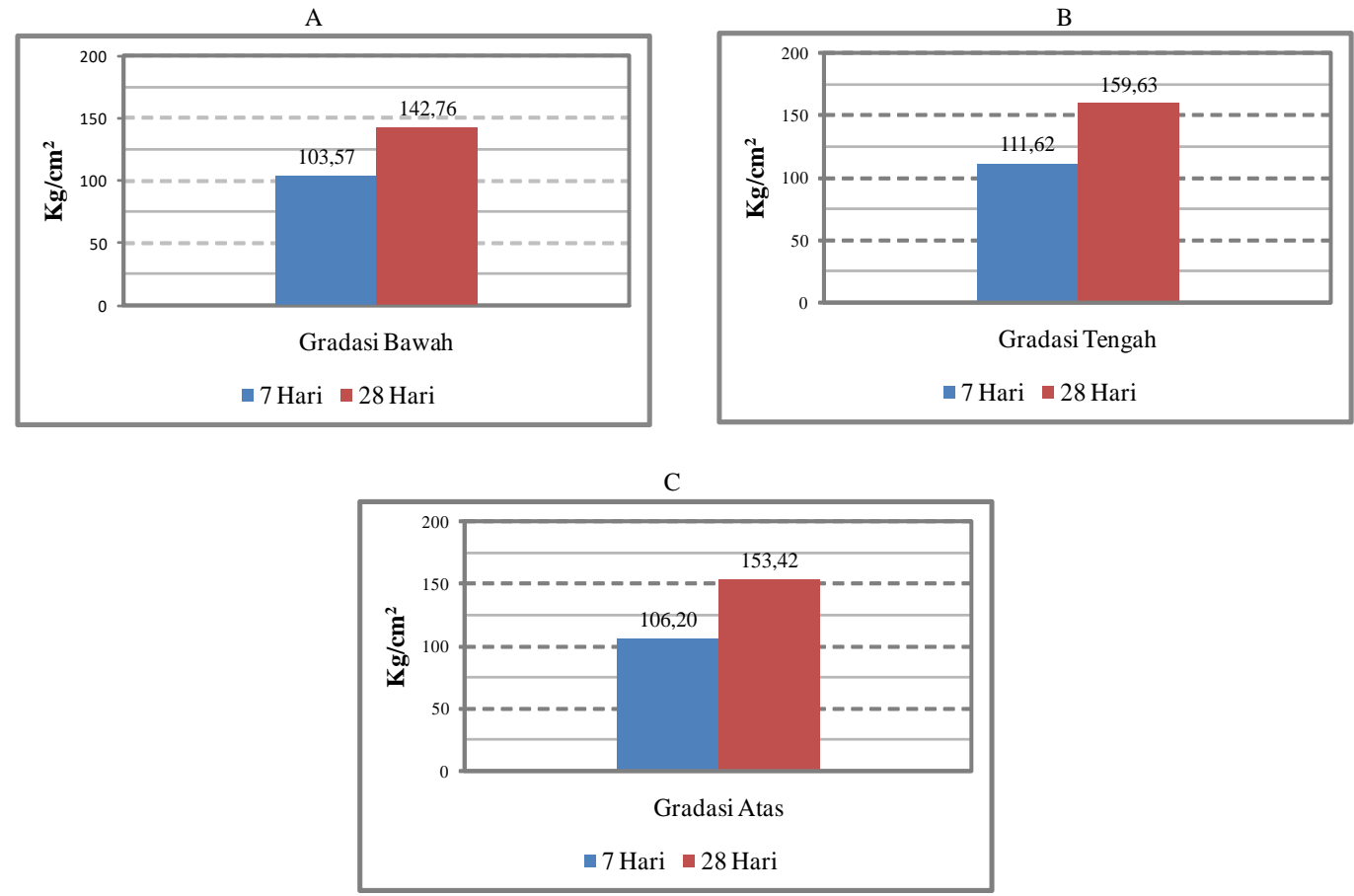

Gambar 1. Grafik Kuat Tekan Umur 7 dan 28 hari untuk tiap tipe gradasi 
Dari gambar 1 diketahui nilai kuat tekan benda uji untuk masing-masing variasi gradasi memenuhi syarat yang ditentukan. Untuk gradasi bawah, didapat nilai kuat tekan pada umur 7 hari sebesar 103,57 $\mathrm{kg} / \mathrm{cm}^{2}$, sedangkan untuk umur 28 hari, didapat nilai kuat tekan sebesar $153,42 \mathrm{~kg} / \mathrm{cm}^{2}$. Sementara untuk gradasi tengah, didapat nilai kuat tekan pada umur 7 hari sebesar 111,62 kg/cm ${ }^{2}$, dan untuk umur 28 hari nilai kuat tekan yang diperoleh sebesar $159,63 \mathrm{~kg} / \mathrm{cm}^{2}$. Dan untuk gradasi atas, didapat nilai kuat tekan pada umur 7 hari sebesar, 106,20 kg/ $\mathrm{cm}^{2}$, sedangkan untuk umur 28 hari, didapat nilai kuat tekan sebesar 153,42 $\mathrm{kg} / \mathrm{cm}^{2}$. Dari keseluruhan hasil kuat tekan tersebut didapat nilai rata-rata dari kuat tekan dari umur 7 hari terhadap umur 28 hari yaitu sebesar 70,57\%.

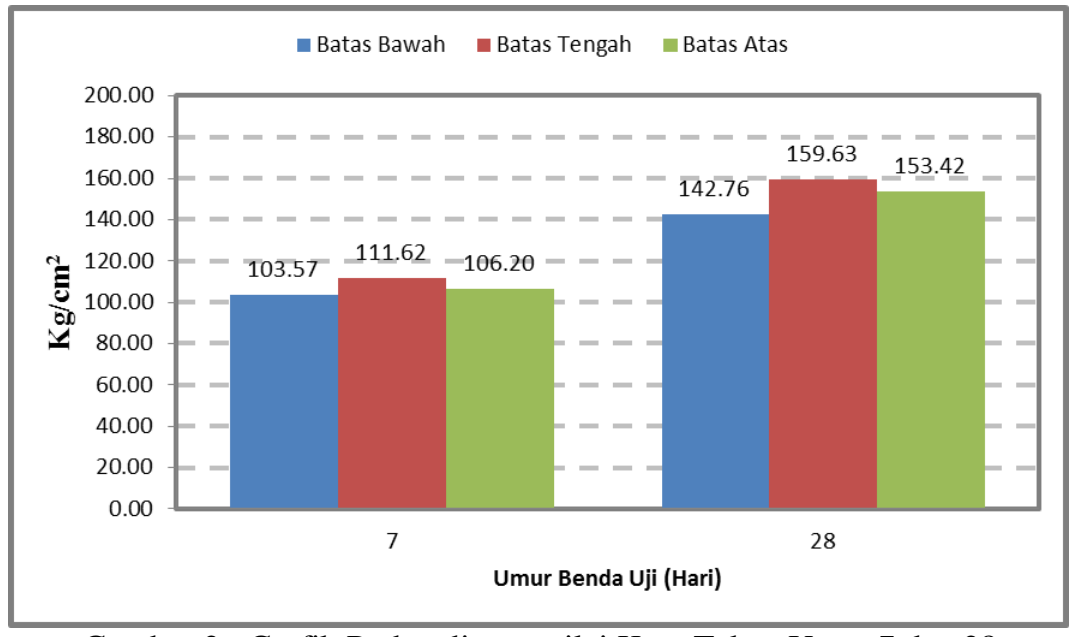

Gambar 2 : Grafik Perbandingan nilai Kuat Tekan Umur 7 dan 28

Gambar 2 menunjukkan nilai rata-rata kuat tekan benda uji CTB untuk gradasi tengah memiliki nilai kuat tekan lebih tinggi dibandingkan dengan gradasi bawah dan gradasi atas. Sedangkan nilai gradasi atas, memiliki nilai kuat tekan yang lebih tinggi dibandingkan dengan nilai kuat tekan gradasi bawah.Hal tersebut dapat dilihat dari nilai kuat tekan gradasi tengah pada umur 7 hari adalah $111,62 \mathrm{~kg} / \mathrm{cm}^{2}$ dan untuk nilai kuat tekan umur 28 hari adalah 159,63 kg/ $\mathrm{cm}^{2}$, nilai kuat tekan gradasi atas pada umur 7 hari adalah 106,20 $\mathrm{kg} / \mathrm{cm}^{2}$ dan dan nilai kuat tekan untuk umur 28 hari adalah $153,42 \mathrm{~kg} / \mathrm{cm}^{2}$, dan untuk nilai kuat tekan gradasi bawah untuk umur 7 hari adalah 103,57 kg/cm2, nilai kuat tekan pada umur 28 hari adalah $142,76 \mathrm{~kg} / \mathrm{cm}^{2}$.

Tabel 4. Persentase perbandingan kuat tekan gradasi atas dan gradasi bawah terhadap gradasi tengah

\begin{tabular}{|c|c|c|c|c|c|}
\hline \multirow{2}{*}{ Umur (Hari) } & \multicolumn{3}{|c|}{ Kuat Tekan $\left(\mathrm{kg} / \mathrm{cm}^{2}\right)$} & \multirow{2}{*}{ GB/GT } & \multirow{2}{*}{ GA/GT } \\
\hline & GB & GT & GA & & \\
\hline 7 & 103,57 & 116,62 & 106,20 & $92,78 \%$ & $95,14 \%$ \\
\hline 28 & 142,76 & 159,63 & 153,42 & 89,435 & $96,11 \%$ \\
\hline
\end{tabular}

Dari hasil data tabel 4 maka dapat diketahui perbandingan kuat tekan gradasi bawah terhadap gradasi tengah, pada umur 7 hari $=92,78 \%$ dan umur 28 hari $=89,43 \%$. Untuk nilai kuat tekan gradasi atas terhadap gradasi tengah, pada umur 7 hari $=95,14 \%$ dan umur 28 hari $=96,11 \%$.

\section{SIMPULAN}

Berdasarkan hasil penelitian dan pembahasan, simpulan penelitan ini adalah:

1. Nilai kuat tekan umur 7 hari untuk gradasi bawah adalah $103,57 \mathrm{~kg} / \mathrm{cm}^{2}$, Nilai kuat tekan gradasi tengah pada umur 7 hari adalah 111,62 kg/cm ${ }^{2}$, dan nilai kuat tekan gradasi atas pada umur 7 hari adalah106,20 $\mathrm{kg} / \mathrm{cm}^{2}$. Nilai kuat tekan umur 28 hari untuk gradasi bawah adalah $142,76 \mathrm{~kg} / \mathrm{cm}^{2}$, nilai kuat tekan umur 28 hari untuk gradasi tengah adalah $159,63 \mathrm{~kg} / \mathrm{cm}^{2}$, dan nilai kuat tekan umur 28 hari untuk gradasi atas adalah $153,42 \mathrm{~kg} / \mathrm{cm}^{2}$.

2. Dari hasil pengujian nilai kuat tekan gradasi tengah memiliki nilai kuat tekan lebih tinggi dibandingkan dengan gradasi atas dan gradasi bawah hal ini dikarenakan ukuran setiap butiran terdistribusi dengan baik sehingga pori-pori yang terdapat pada CTB lebih sedikit. Gradasi atas memiliki nilai kuat tekan yang 
lebih tinggi dibandingkan batas bawah, hal ini dikarenakan pada gradasi bawah memiliki agregat halus lebih sedikit, sehingga terdapat banyak pori-pori pada benda uji tersebut.

\section{DAFTAR PUSTAKA}

.1989, SNI 03-1737-1989, Tata cara Pelaksanaan Lapis Aspal Beton (LASTON untuk Jalan Raya,

Badan Standardisasi Nasional (BSN). .1990, SNI 03-1968-1990, Metode Pengujian Tentang Analisis Saringan

Agregat Halus dan Kasar, Badan Standardisasi Nasional (BSN). .1996, SNI 03-4141-1996, Metode Pengujian Gumpalan Lempung dan Butir-butir Mudah Pecah

Dalam Agregat, Badan Standardisasi Nasional (BSN). .2000, SNI 03-6429-2000, Metode pengujian kuat tekan beton silinder dengan cetakan silinder di

dalam tempat cetakan, Badan Standardisasi Nasional (BSN). 2004, SNI 15-2049-2004, Semen Portland, Badan Standardisasi .2008, SNI 2417-2008, Cara uji Keausan Agregat Dengan Mesin

Standardisasi Nasional (BSN). $(\mathrm{BSN})$. .2008, SNI 1967-2008, Cara Uji Penentuan batas cair untuk tanah , Badan Standardisasi Nasional .2008, SNI 1966-2008, Cara Uji Penentuan Batas Plastis Dan Indeks Plastisitas , Badan Standardisasi Nasional (BSN). .2008, SNI 1969-2008, Metode Pengujian Berat Jenis dan Penyerapan Air Agregat Kasar, Badan

Standardisasi Nasional (BSN). .2008, SNI 1970-2008, Metode Pengujian Berat Jenis dan Penyerapan Air Agregat Halus, Badan Standardisasi Nasional (BSN). .2008, SNI 1743-2008, Metode pengujian kepadatan berat untuk tanah, Badan Standardisasi Nasional (BSN). .2010, Kementerian Pekerjaan Umum. 2010, Spesifikasi Umum 2010 (Revisi 3).

BS. Hananto. 1993. Penggunaan Cement Treated Base sebagai lapisan Konstruksi Perkerasan.

Departemen Pekerjaan Umum Direktorat Jendral Bina Marga, 2006, Manual konstruksi dan Bangunan, Buku 4,Lapis Pondasi Agregat Semen.

Desmawaty, Ni Made Dwi, 2014. Kajian Terhadap Karakteristik Campuran CTB ( Cement Treated Base )

Dan CTRB ( Cement Treated Recling Base ), Universitas Lampung, Lampung.

Harry, Suhartono, Richard, dan Fransisca, Maret 2001, "Dimensi Teknik Sipil". Volume 3, No. 1, Penelitian

Pendahuluan Penggunaan Benda Uji Kubus Beton Pada Perkerasan Lentur Type Cement Treated Base (CTB).

Hidayat, Syarif. 2009. Semen Jenis dan Aplikasinya, Kawan Pustaka. Jakarta.

Kementerian Pekerjaan Umum. 2010. Pengendalian Mutu Pekerjaan Beton. Bandung: Balai Jembatan dan Bangunan Pelengkap Jalan.

Ramadhani, Sandi Tizar, 2015. Perbandingan Kuat Tekan Cement Treated Base (CTB) Dengan Menggunakan Semen Padang Tipe OPC (Ordinary Portland Cement) Dan PCC (Portland Composite Cement), Universitas Batanghari, Jambi.

Soja Siti Fatimah, 2008, Produksi Semen, http://file. upi. edu/ Direktori/ FPMIPA/ JUR._PEND. _KIMIA/ $196802161994022-$

Sukirman, Silvia. 1999. Perkerasan Lentur Jalan Raya. Nova, Bandung. 